\title{
Michael Tierney and the Intellectual Origins of Blueshirtism, 1920-1938
}

\author{
Seán Donnelly \\ School of Social Sciences, Humanities and Law, Teesside University, \\ Middlesbrough, United Kingdom \\ sean.donnelly@ucdconnect.ie
}

\begin{abstract}
The Blueshirts have been one of the most contested and extensively researched subjects in twentieth-century Irish historiography. Debate has focused principally on the extent to which the movement should be understood as a fascist organisation, or as a spontaneous counter-reaction to the domestic political instability that followed Fianna Fáil's victory in the $193^{2}$ general election. However, strikingly little attention has been devoted to tracing the intellectual origins of Blueshirtism in Irish nationalist and republican thought. This article rejects the dominant historiographical representation of the Blueshirts as an aberration in Irish political history and suggests that the movement can only be understood properly in continuity with the political thought of the pre-Civil War period. It is argued, additionally, that the more complex and differentiated 'hybrid' theories of 'fascistization' developed by scholars like David D. Roberts, António Costa Pinto and Aristotle Kallis provide a useful comparative framework for understanding how nationalist intellectuals such as Michael Tierney, once steadfast in their commitment to the norms of parliamentary democracy, came to endorse a corporatist politics after being voted out of office.
\end{abstract}

\section{Keywords}

Irish Free State - Blueshirts - nationalism - republicanism - fascism - corporatism - modernization - Catholicism - Michael Tierney (1894-1975)

Since the publication of Maurice Manning's influential 1970 monograph, The Blueshirts, the Eoin O'Duffy-led, paramilitary organisation with which Cumann 
na nGaedheal merged to form Fine Gael in September 1933, has been one of the most contested and extensively researched subjects in twentieth-century Irish historiography. Debate has focused principally on the extent to which the movement should be understood as a fascist organisation akin to the Nazi Brownshirts and Italian Blackshirts, or as a predominantly domestic political phenomenon - 'a final instalment of the Civil War saga.' ${ }^{1}$ Manning established the tone for much early writing on the Blueshirts when he argued that, although the movement 'drew some of its inspiration and some of its practices' from contemporary fascist organisations on the European continent, it was 'essentially' an 'Irish phenomenon, for most of the factors which influenced its growth and origin were the products of conditions peculiar to Ireland.' This perspective, of course, overlooks the fact that all fascist movements, while drawing on foreign influences, are products of particular national-historical settings and are shaped by distinct, domestic political phenomena. Drawing on a growing body of scholarship concerned to take the intellectual history of fascism seriously, Mike Cronin revised significant aspects of Manning's thesis and articulated what has become the consensus view on the Blueshirts when he characterised the organisation as 'para-fascist'; that is, as an alteration or perversion of the generic typology of fascism theorised in Roger Griffin's influential 1991 publication, The Nature of Fascism. ${ }^{3}$

In Cronin's analysis, the Blueshirts may be understood accurately as 'a Salazaresque' movement which adopted 'many of the trappings of fascism' but which lacked the explicitly anti-democratic, revolutionary zeal of the paradigmatic fascist regimes established in contemporary Italy and Germany. ${ }^{4} \mathrm{Had}$ O'Duffy's organisation ever acceded to executive power, Cronin argued, they would have resembled the corporatist authoritarianism of António de Oliveira Salazar's Portugal, Engelbert Dollfuss' Austria or Francisco Franco's Spain; states that adopted aspects of fascism to defend established conservative institutions, such as the church and army, but regarded radical, revolutionary fascism as a threat. ${ }^{5}$ As Fearghal McGarry reflected in his biography of O'Duffy, a Blueshirt regime, 'like the dictatorships of Franco's Spain and Dollfuss's Austria', would have 'defended the primacy of a constellation of conservative interests: property, church, family, the military, the administration'; however, 'There would have been little attempt to control private initiative, religious freedom, civil society, or the family.' ${ }^{6}$ In this perspective the Blueshirts can

\footnotetext{
Maurice Manning, The Blueshirts (Dublin: Gill and Macmillan, 1970), 248.

2 Manning, The Blueshirts, 250.

3 Roger Griffin, The Nature of Fascism (London: Routledge, 1991), 116-145.

$4 \quad$ Mike Cronin, 'The Blueshirt Movement, 1932-5: Ireland's Fascists?' Journal of Contemporary History 30 (1995): 327-3o, https://doi.org/10.1177/oo2200949503000206.

$5 \quad$ Mike Cronin, The Blueshirts and Irish Politics (Dublin: Four Courts Press, 1997).

6 Fearghal McGarry, Eoin O'Duffy: A Self-Made Hero (Oxford: Oxford University Press, 2005), 243.
} 
be assessed most productively as one of the many 'abortive manifestations of fascism' in interwar Europe; that is, as a movement 'which, though undoubtedly both anti-liberal and anti-communist, sought to fulfil goals which were insufficiently palingenetic or ultra-nationalist in their inspiration to lead even in principle to the creation of a new national community through the radical overhaul of existing political, economic, ideological and social structures. ${ }^{7}$

But for all that the contributions of scholars such as Manning, Cronin and McGarry have contributed to deepen our understanding of the complex social, political and economic factors that precipitated the rise of the Blueshirts, strikingly little attention has been devoted to tracing the ideological origins of the movement in order to better understand how many figures involved in an anti-imperial, republican revolution in 1916 came to endorse some species of fascism in the 1930s. Indeed, the tendency of many Irish historians to weigh and measure the ideology and policy programme of the Blueshirts against models of generic fascism retrospectively theorised in later twentieth-century scholarship obscures the fact that the development of fascism in the 1920 and ' 3 os was a highly contingent, dynamic and open-ended process, one that occurred at a time when many essential characteristics of Italian Fascism and German National Socialism were not fully apparent to external observers. Sensitive to the heterogeneity and contestedness of interwar fascist thought, scholars have grown less concerned with traditional, taxonomic debates aimed at establishing the fascist credentials of particular regimes. Focus has shifted instead to what Constantin Iordachi terms the 'trans-national cross-fertilization of illiberal political ideas and practices' 8 in interwar Europe: that is, the dynamic processes through which conservative, ultra-nationalist, anti-liberal and anti-socialist intellectuals learned from one another and exchanged ideas in developing a range of illiberal institutional and policy responses to the social and economic challenges of the 1930s. ${ }^{9}$ This 'transnational turn' in contemporary fascist studies eschews any attempt to pin down a static, procrustean definition of fascism and seeks instead to excavate the complex web of interaction that composed the intellectual constellation of the interwar European Right. ${ }^{10}$

$7 \quad$ Griffin, The Nature of Fascism, 117.

8 Constantin Iordachi, 'Fascism in Interwar East Central and Southeastern Europe: Toward a New Transnational Research Agenda,' East-Central Europe 37 (2010): 195, https://doi.org/10 $.1163 / 187633010 X_{541786 .}$

9 Aristotle Kallis, 'Neither Fascist nor Authoritarian: The 4th of August Regime in Greece (1936-41) and the Dynamics of Fascistisation in 1930s Europe,' East Central Europe 37 (2010): 303-33o, https://doi.org/10.1163/187633010X534504. 
In this framework, fascism is understood not as a fixed programme or doctrine, but as 'an uncertain open-ended dynamic with no fixed essence, ${ }^{11}$ a broad set of institutional arrangements, liturgical practices and political beliefs subject to selective, reflexive, and adaptive borrowing by more conventional conservative and authoritarian movements seeking to develop an alternative to both liberalism and socialism. As Aristotle Kallis has argued forcefully: 'The... distinction between "fascist" and "para-fascist" regime is problematic because it assumes a common and static understanding of what fascism meant to its contemporaries. The meaning of "fascism" continued to evolve, change contours and diversify throughout the 1920 and 1930s, resulting in a host of different understandings. ${ }^{12}$

This 'new approach' to fascist studies, ${ }^{13}$ emphasising the heterogeneous, interconnected and 'hybrid' character of interwar conservative and nationalist thought, has the potential to deepen significantly our understanding of the radicalisation of several senior Treatyite intellectuals in the years following Fianna Fáil's accession to executive power. ${ }^{14}$ For what changed in Ireland after 1932 was not only the balance of political power in the Free State, but also the international intellectual climate in which the already virulently anti-liberal and anti-socialist Catholic intellectuals who assumed leadership of the Blueshirt movement conceptualised and articulated their political aspirations. By the time Cumann na nGaedheal merged with the Blueshirts in 1933, right-wing authoritarian movements had swept to power in Hungary (1920), Italy (1922), Spain (1923-30), Portugal (1926), Poland (1926), Albania (1929), Yugoslavia (1929), Germany (1933) and Austria (1933), and analogous movements would soon succeed in Estonia (1934), Latvia (1934), Bulgaria (1934), Lithuania (1936), Greece (1936) and Romania (1938)..${ }^{15}$ Inevitably, these developments impacted upon the political thought of conservative nationalist and

David D. Roberts, 'Fascism and the Framework for Interactive Political Innovation during the Era of the Two World Wars,' in Rethinking Fascism and Dictatorship in Europe, ed. António Costa Pinto and Aristotle Kallis, 57.

Aristotle Kallis, "Fascism", "Para-fascism" and "Fascistization": On the Similarities of Three Conceptual Categories', European History Quarterly 33 (2003): 221, https://doi. org/10.1177/02656914030332004.

David D. Roberts, Fascist Interactions: Proposals for a New Approach to Fascism and Its Era, 1919-45 (New York: Berghahn Books, 2016).

The term 'Treatyite' refers here to those who endorsed the ratification of the Anglo-Irish Treaty in Dáil Éireann on 7 January 1922 and supported thereafter the state-building programme implemented by the ruling Cumann na nGaedheal government (1923-1932). Roger Griffin, 'Mussolini Predicted a Fascist Century: How Wrong Was He?' Fascism:Journal of Comparative Fascist Studies 8 (2019): 3-4, https://doi.org/10.1163/22116257-0o8010o1. 
Catholic intellectuals throughout Europe, and Ireland was no exception. ${ }^{16}$ However, the significance of such geopolitical transformations in shaping Treatyite thought has been obscured as a consequence of a widespread scholarly tendency to isolate the Blueshirts from the anti-imperial, republican revolution that culminated in the institutionalisation of the Free State.

In most accounts the Blueshirts are depicted as 'an aberration in Irish political history, ${ }_{17}^{17}$ a deviation from the liberal and democratic path of development articulated by the leaders of the revolution and the subsequent Cumann na nGaedheal government. ${ }^{18}$ Fearghal McGarry, for instance, identifies the origins of Blueshirtism in the 'crisis of conservative or treatyite politics in Ireland between 1932 and 1934', framing the movement as the 'reactionary' response of a 'radicalised' section of the 'treatyite elite' to the experience of being 'rejected by the electorate in [1932 and] $1933 \cdot{ }^{19}$ Mike Cronin depicts 'Ireland's brief flirtation with fascism in the early $193{ }^{\circ}{ }^{\prime 20}$ as a 'reaction to the political ineptitude of Cumann na nGaedheal' and the party's 'recent history of political misfortune and defeat', avowing conclusively that the movement 'presented ideas which were alien to the heritage of Cumann na nGaedheal. ${ }^{21}$ Maurice Manning labelled the Blueshirts 'essentially a product of the [nineteen-]thirties', concluding that 'the main importance' of the movement 'lies in its uniqueness. ${ }^{22}$ Michael Laffan refers to a 'Blueshirt Parenthesis'23 in his account of the realignment of Free State politics that followed the $193^{2}$ general election, dismissing the movement as 'basically defensive and harmless' and 'less violent than the republican extremists' they set out to oppose. ${ }^{24}$ In this perspective, the

16 See, for example, Fearghal McGarry, Irish Politics and the Spanish Civil War (Cork: Cork University Press, 1999); Mark Phelan, 'Irish Responses to Fascist Italy, 1919-1932' (PhD thesis, National University of Ireland, Galway, 2013).

17 Cronin, The Blueshirts, 12.

18 See, for example, Tom Garvin, 1922: The Birth of Irish Democracy (Dublin: Gill \& Macmillan, 1996).

Fearghal McGarry, 'Catholicism and Fascism in Interwar Ireland,' in Catholicism and Fascism in Europe 1918-1945, ed. Jan Nelis, Anne Morelli and Danny Praet (Hildesheim: Georg Olms Verlag, 2015), 113-114.

Mike Cronin, 'Catholicising Fascism, Fascistising Catholicism? The Blueshirts and the Jesuits in 1930s Ireland,' Totalitarian Movements and Political Religions 8 (2007): 401, https://doi.org/10.1080/14690760701321395.

21 Cronin, The Blueshirts, 64, 74.

22 Manning, The Blueshirts, 2, 250.

23 Michael Laffan, Judging W.T. Cosgrave: The Foundation of the Irish State (Dublin: Royal Irish Academy, 2014), 305-311.

24 Michael Laffan, The Resurrection of Ireland: The Sinn Féin Party, 1916-1923 (Cambridge: Cambridge University Press, 1999), 448. 
Treatyites' 'brief, disastrous flirtation with paramilitary extremism'25 under the leadership of O'Duffy was merely a peculiar interlude in the otherwise seamless process by which the old Cumann na nGaedheal government transitioned into its new role as leaders of a democratic opposition. Jason Knirck neglects even to mention the Blueshirts in his study of Cumann na nGaedheal's final years in office, implicitly isolating the movement from the constitutional party with which it merged to form Fine Gael in $1933 .{ }^{26}$ Ciara Meehan, meantime, denies any meaningful ideological connection between Cumann na nGaedheal and the Blueshirts, stating conclusively that 'Cumann na nGaedheal's legacy is not the Blueshirts, but rather an underlying commitment to building and upholding the structures of the state.27

This tendency to distance the Blueshirts both from the Irish revolution and the Cumann na nGaedheal government that was formed to assume control of the Free State has obscured our understanding of the movement's relation to the broader nationalist and republican tradition. It has further prevented us from understanding the place of Irish intellectuals in the trend 'of elite political radicalisation', ${ }^{28}$ or 'fascistisation', that occurred throughout Europe in the 1920 s and ' 30 . This was the process through which large sectors of the European Right were drawn into the 'political gravitational field of fascism'29 and engaged in 'a controlled adoption of fascist novelties without subscribing to fascism's overall ideological vision. ${ }^{30}$ As Kallis notes, the success of fascist and corporatist regimes across 1930s Europe charted new, previously inaccessible paths of radical political action and provided sympathetic observers with both 'a legitimizing precedent' and 'a developing toolkit' for revolutionary political change. ${ }^{31}$ Put simply, a large number of conservative nationalist and Catholic intellectuals in interwar Europe recognised in states such as Italy, Portugal and Austria a single - successful and increasingly desirable - alternative to both liberalism and socialism, a political dispensation capable of reconciling the social and economic crises of the interwar period. ${ }^{32}$

Laffan, Judging W.T. Cosgrave, 4. Jason Knirck, Afterimage of the Revolution: Cumann na nGaedheal and Irish Politics, 19221932 (Madison: Wisconsin University Press, 2014).

Ciara Meehan, The Cosgrave Party: A History of Cumann na nGaedheal, 1923-33 (Dublin: Royal Irish Academy, 2010), 224.

Kallis, 'Neither Fascist nor Authoritarian,' 330.

Roberts, Fascist Interactions, 32.

Kallis, "'Fascism", "Para-fascism" and "Fascistization"', 221.

Aristotle Kallis, "The "Fascist Effect": On the Dynamics of Political Hybridization in Inter-War Europe,' in Rethinking Fascism and Dictatorship in Europe, ed. António Costa Pinto and Aristotle Kallis (Basingstoke: Palgrave, 2014), 32.

For more on the complex, ambivalent reception of Nazi ideology in Ireland, see Mervyn O'Driscoll, Ireland, Germany and the Nazis: Politics and Diplomacy, 1919-1939 (Dublin: 
Of particular interest in this regard are those men identified frequently as constituting the Blueshirts's intellectual leadership; notably, Michael Tierney and John Marcus Sullivan of University College, Dublin (UCD); James Hogan of University College, Cork; and Ernest Blythe and Desmond FitzGerald, both ex-ministers in the Cumann na nGaedheal government of the 1920 . Indeed, with the exception of O'Sullivan, a Cumann na nGaedheal Minister for Education and, subsequently, for Finance, all the senior Blueshirt intellectuals listed above were involved with separatist-nationalist organisations prior to the revolution. FitzGerald fought alongside the leader of the Easter Rising, Patrick Pearse in General Post Office; ${ }^{33}$ Blythe was a leading organiser in the Irish Republican Brotherhood (IRB) and Irish Volunteers long before 1916, ${ }^{34}$ while Tierney and Hogan each joined the Volunteers as undergraduate students at UCD (Hogan was further sworn into the IRB in 1915). ${ }^{35}$ Rather than simply sectioning the Blueshirts off from the wider nationalist tradition, these connections oblige us to attempt to understand how figures once seemingly steadfast in their commitment to the norms of parliamentary democracy grew increasingly open to radical, potentially authoritarian alternatives in the 193os. Such continuities further compel us to think more critically about the potential for fascism in Irish nationalist thought as it developed from the later nineteenth-century. For too often overlooked in scholarly accounts of the Blueshirts an 'aberration in Irish politics' ${ }^{36}$ is the simple fact that the movement's leadership never ceased to conceive of or represent themselves as inheritors of the nationalist and republican ideas that animated the revolution. Addressing a Blueshirt rally in Ballyshannon in December 1933, for instance, O'Duffy declared himself a 'Republican' and avowed that it is the racially 'half-breed' Éamon de Valera who 'runs away from the Republic and arrests you Republicans and puts you in board beds in Mountjoy [Gaol]',37

Four Courts Press, 2004); see also R.M. Douglas, Architects of the Resurrection: Ailtiri na hAiséirghe and the Fascist 'New Order' in Ireland (Manchester: Manchester University Press, 2009).

Desmond FitzGerald, Desmond's Rising: Memoirs, 1913 to Easter 1916 (London: Routledge \& Kegan Paul, 1968).

David Fitzpatrick, Ernest Blythe in Ulster: The Making of a Double Agent? (Cork: Cork University Press, 2018).

35 See Henry Boylan, 'Tierney, Michael,' in A Dictionary of Irish Biography (Dublin: Barnes and Noble, 1978), 351; E.M. Hogan, 'James Hogan: A Biographical Sketch,' in James Hogan: Revolutionary, Historian and Political Scientist, ed. Donnchadh Ó Corráin (Dublin: Four Courts Press, 2001), $1-34$. McGarry, Eoin O'Duffy, 227. 
Blythe struck a similar tone at a meeting in Tipperary the following year, styling 'the Blueshirts' as 'the authentic successors of the Volunteers.' ${ }^{38}$

There can be no doubt that the fraught political climate of Free State politics in the immediate aftermath of Fianna Fáil's accession to power is essential to understanding the radicalisation of Treatyite thought in the 1930s. ${ }^{39}$ There were acute fears that de Valera's relationship with the IRA and his alleged communist sympathies would imperil Irish democracy, ${ }^{40}$ and many Cumann na nGaedheal voters, particularly large cattle farmers, opposed virulently Fianna Fáil's decision to engage in a trade war with the United Kingdom at a time of global economic depression..$^{41}$ However, the commonplace perception that the corporatist policies adopted by Fine Gael under the abortive leadership of O'Duffy were 'unreal in the context of Irish politics'42 and 'had no links to the traditions of Cumann na nGaedheal', ${ }^{43}$ fails to account for the significant strands of ideological and rhetorical continuity linking the fascist and corporatist ideas of the Blueshirt movement to the communitarian Catholic conservatism that exerted such a profound influence over pre-Treaty nationalist and republican thought and Treatyite politics after 1922.

This article seeks to reconnect the Blueshirts with the pre-Treaty nationalist tradition, highlighting how many of the themes and ideas that animated the movement can be observed in nationalist and republican discourses from the late nineteenth century. Paying particular attention to the work of Michael Tierney, a figure cited regularly as the foremost intellectual influence in shaping the ideology and policy programme of the Blueshirts under O'Duffy's leadership ${ }^{44}$ it will be suggested that a dynamic process of intellectual engagement with political ideas and events on the European continent was critical in fomenting the emergence of a radical alternative to liberal parliamentarianism in the Free State after 1932. Such an approach, it is hoped, might enable us to acquire a more nuanced perception of the Blueshirts' self-understanding as fascism developed during the 1920 and '3os. Crucially, it will be argued that

$38 \quad$ Cited in Brian Hanley, 'The Rhetoric of Republican Legitimacy' in Republicanism in Modern Ireland, ed. Fearghal McGarry (Dublin: UCD Press, 2003), 167-177.

39 Mel Farrell, Party Politics in a New Democracy: The Irish Free State, 1922-37 (New York: Palgrave, 2017), 271-272.

40 John M. Regan, The Irish Counter-Revolution, 1921-36: Treatyite Politics and Settlement in Independent Ireland (Dublin: Gill \& Macmillan, 2001), 279-340.

Mike Cronin, "The Socio-Economic Background and Membership of the Blueshirt Movement, 1932-5,' Irish Historical Studies 29 (1994): 234-249, https://doi.org/10.1017/ Soo21121400011597. 
a conservative Irish nationalist and republican, such as Tierney, could reject democracy and endorse a corporatist programme for government without consciously repudiating the core political aspirations to which he had given expression in the past. In this perspective, the potential for an anti-democratic, corporatist or fascist turn can be seen to have been latent in certain strands of Irish nationalist thought long before the formation of Fine Gael. The fraught conditions of Free State politics after 1932 might, therefore, be better understood as catalysing an extreme, programmatic expression of long-established anti-individual, anti-materialist and (latently) anti-democratic concepts in nationalist thought rather than as a transformative moment that altered fundamentally the political ideas of former republican and Treatyite intellectuals such as Tierney, Blythe and FitzGerald. This more fully contextualised interpretation of the ideological origins of Blueshirtism, it is hoped, might function to complicate the commonplace perception of the movement as an aberration in the otherwise seamless liberal, democratic trajectory of Irish political history.

\section{A Vision for Modern Ireland}

Born into modest circumstances on a small farm near Ballinasloe in Co. Galway in 1894, Michael Tierney was an unlikely candidate to achieve a distinguished career as an academic and politician. ${ }^{45} \mathrm{He}$ was appointed Professor of Greek at UCD in 1922 and, the following year, married the eldest daughter of the prominent nationalist historian and politician, Eoin MacNeill, Eibhlín. A staunch supporter of the Anglo-Irish Treaty, he served as honorary secretary for the ruling, Cumann na nGaedheal party from 1923 and was elected as T.D. for Mayo North (1925-27) and for the NUI constituency (1927-1932). Upon losing his Dáil seat in 1932, Tierney played a key role in negotiating the merger of Cumann na nGaedheal with the Army Comrades Association and the National Centre Party and became a strong advocate of corporatist ideas in Irish public life in his role as Vice-President of Fine Gael alongside James Hogan. By August 1934, however, Tierney, like Hogan, had grown increasingly disillusioned with O'Duffy's erratic leadership and resigned from the party in protest at O'Duffy's plan to campaign against the ruling Fianna Fáil government's collection of land annuities. ${ }^{46}$ He was elected subsequently to the NUI Panel of Seanad Éireann

\footnotetext{
45 See Peter Martin, 'The political career of Michael Tierney, 1920-44,' Irish Historical Studies, 37 (2011), 412-26, https://doi.org/10.1017/Soo21121400oo273X.

46 McGarry, Eoin O'Duffy, 26o-269.
} 
in 1938 where, ${ }^{47}$ in his role on the Committee for Vocational Organisation, he continued to promote corporatist ideas. Shortly after losing his Seanad seat in 1943, Tierney was elected president of UCD by the senate of the National University. He retired from that position in 1964 and died aged 8o in 1975.

Tierney's earliest contribution to political discourse, Education in a Free Ireland (1920) looks forward to the development of a state educational system under the control of a native government. ${ }^{48}$ Writing against the backdrop of the War of Independence, Tierney was convinced that although 'the immediate need is to get England out' of Ireland, 'we cannot propose to build an Irish Republic upon a vacuum' and must, therefore, cultivate 'an all-embracing economic and social policy', one rooted in an autochthonous culture and Gaelic intellectual traditions. ${ }^{49}$ Understood as a derivative or immature expression of the Irish-Ireland nationalism that predominated among Catholic intellectuals in the decades preceding the Easter Rising, ${ }^{50}$ Education in a Free Ireland has been overlooked by historians concerned to identify the origins and development of Blueshirtism after 1932. Indeed, the Irish-Ireland movement is dismissed frequently as parochial and backward-looking, a deeply Catholic and therefore intrinsically retrograde ideology, animated by a crude admixture of sectarianism and Anglophobia, that was concerned principally to cut Ireland off the from the modern world. ${ }^{51}$ Such perspectives, rooted in a reductive, moralistic conception of modernity as a synonym for social and economic liberalisation, ${ }^{52}$ prevent us from recognising how Irish-Ireland nationalism's loathing of the disenchanting and anomic aspects of modernity was intrinsic to its imagining of an alternative political future. Marshall Berman, for instance, reminds us, that 'to be fully modern is to be anti-modern'; it is 'to live a life of paradox and contradiction', to be 'both revolutionary and conservative', to 'embrace the modern world's potentialities [while] loathing and fighting against some of its most palpable realities. ${ }^{53}$ In the writings of the separatist-nationalist

Seanad Éireann is the upper house of the Oireachtas (the Irish legislature), which also comprises the President of Ireland and Dáil Éireann (the lower house).

48 Michael Tierney, Education in a Free Ireland (Dublin: Martin Lester, 1920).

49 Tierney, Education in a Free Ireland, iv-vi.

50 Brian Ó Conchubhair 'The Culture War: The Gaelic League and Irish Ireland,' in The Cambridge History of Ireland: Volume 4, 1880 to the Present, ed. Thomas Bartlett (Cambridge: Cambridge University Press, 2018), 196-220. See, for example, Richard English, Irish Freedom: A History of Nationalism in Ireland (Basingstoke: Routledge, 2006).

$5^{2}$ See, for example, R. F. Foster, Modern Ireland, 1600-1972 (London: Allen Lane, 1988); Tom Garvin, Preventing the Future: Why was Ireland so Poor for so Long? (Dublin: Gill \& Macmillan, 2004).

Marshall Berman, All That Is Solid Melts into Air: The Experience of Modernity (London: Penguin, 1988), 13-14. 
leadership, 'Gaelic Ireland' was invoked, not as a feudal redoubt into which the nation could retreat and shut itself off from 'the anarchy of modern times, ${ }^{54}$ but as a model on which an independent Irish state could fashion its reception of modernity, translating 'the spirit of the old Irish State into modern conditions'.55 As Tierney put it, Sinn Féin needed to create 'not only the Gaelic state of the past, but the Christian state of the future'.56

This aspiration to shape a distinctly Gaelic-Catholic variant of modernity forms a vital element of continuity linking the political thought of the Blueshirt movement to the pre-Treaty nationalist tradition. For as most scholars now recognise, fascism cannot be understood accurately as anti-modern; that is, as a reaction against the transformative social and political effects of industrialisation and democracy. ${ }^{57}$ Drawing on mythic images of a heroic national past, fascist intellectuals across Europe conceived of themselves as engaged in creating an alternative modernity, and embraced modern technologies and ideas in seeking to plot a spiritually regenerative middle-path between the twin excesses of liberal individualism and socialist collectivism. In most cases, this involved a quest to cleanse mass, industrial society of its disenchanting, decadent and anomic qualities in an effort to reconnect atomised populations with a sense of the transcendent. ${ }^{58}$ Such an insight is essential to understanding how the political thought of the Irish-Ireland movement fed into Blueshirt ideology, for Blueshirtism can be understood productively as an extreme, programmatic expression of the core Irish-Ireland aspiration to shape a distinctly Gaelic-Catholic variant of modernity.

From its origins in the anti-colonial and republican ideologies of the late eighteenth-century, Irish nationalism exhibited a complex and ambivalent attitude to the social and economic transformations wrought by secular, industrial modernity. While the liberal, democratic and republican ideologies that animated the revolutions in America and France held ready appeal for nationalist intellectuals eager to secure greater sovereignty and material prosperity for the people of Ireland, the anomalous nature of the island's historic relation to the British Empire imbued early Irish nationalism with a peculiarly vexed

Aodh de Blácam, From a Gaelic Outpost (Dublin: Catholic Truth Society, 1921), 94. Communist? The Facts of the Case (Dublin: Cahill \& Co., 1935), xi-xii. 
and contingent relation to modernity. ${ }^{59}$ From the Young Irelanders' polemic attacks on the 'selfish creed' of Benthamism, ${ }^{60}$ to Patrick Pearse's fulmination against 'modern utilitarianism' and 'modern decadence, ${ }^{61}$ nationalist and republican intellectuals consistently depicted the individual-focused, economistic logic of Victorian British liberalism as anathema to the social and cultural traditions of Gaelic Ireland. Late nineteenth and early twentieth century nationalist rhetoric consequently focused heavily on the idea of recovering a transcendental national essence that was felt to be threatened by the disembedding forces of modernity. Nationalist leaders such as Pearse and Michael Collins articulated a consistent determination to preserve an inherited body of moral, social and cultural values, qualities embedded in the native language, that would safeguard autochthonous traditions and beliefs and thus enable the Irish nation to 'reconstruct our ancient civilization on modern lines'.62 As the nationalist journalist, Aodh de Blácam wrote, Sinn Féin aspired to render an independent Irish state a 'medieval fragment in the modern world', 63 offering to a continent wearied by narrowly materialist measures of human progress a higher synthesis of the ancient and the modern.

This identification of Irishness with the pre-modern or the defiantly anti-modern was strengthened significantly by the central influence of Catholicism in shaping Irish nationalism. No institution was more directly challenged by the rise of democracy and nation-states than the Roman Catholic Church, and the later nineteenth-century witnessed a flowering of scholasticism in Catholic theology and philosophy as many clergy and members of the lay intelligentsia looked to medieval Christendom for a vision of how Catholics might seek productively to shape modernity. ${ }^{64}$ Perceiving both capitalism and socialism as equally flawed and exploitative, Catholic thinkers across Europe looked to the organisation of medieval trade guilds as a framework to reconcile

See, for example, Joe Cleary, 'Ireland and Modernity', in The Cambridge Companion to Modern Irish Culture, ed. Joe Cleary and Claire Connolly (Cambridge: Cambridge University Press, 2005), 1-22.

6o Cited in David Dwan, The Great Community: Culture and Nationalism in Ireland (Dublin: Field Day, 2008), 51.

$61 \quad$ Patrick Pearse, 'Murder Machine,' in Collected Works of Pádraic H. Pearse: Political Writings and Speeches, Vol. 5 (Dublin: Phoenix, 1922), 13-14.

62 Michael Collins, The Path to Freedom (Dublin: Talbot Press, 1922), 20.

63 Aodh de Blácam, What Sinn Fein Stands For: The Irish Republican Movement; Its History, Aims and Ideals, Examined as to Their Significance to the World (Dublin: Mellifont Press, 1921), xiii.

64 See, for example, Darrell Jodock, ed., Catholicism Contending with Modernity: Roman Catholic Modernism and Anti-Modernism in Historical Context (Cambridge: Cambridge University Press, 2000). 
contemporary tensions between capital and labour, believing that an alternate system of 'joint control between owners and workers' 65 was best placed to ensure social harmony and a widely diffused material prosperity under modern conditions. But whereas in the nineteenth century the Church had focused principally on combating liberalism and socialism through strong rhetorical admonitions, during the Great War the Papacy changed tack and began casting the Vatican as a state-like institution capable of providing practical policy solutions to the European crisis. James Chappel, for instance, has argued forcefully, that it was after World War I that the Catholic Church 'became modern' in that the institution ceased 'fighting to overturn modernity and began agitating for Catholic forms of modernity.' ${ }^{\prime 6}$ In Giuliana Chamedes' formulation, this involved harnessing new communication and transportation technologies to create 'an alternative and uniquely Catholic international European order' via the distinctly modern embrace of national self-determination and international law. ${ }^{67}$ As one sympathetic observer reflected triumphantly in the Irish Jesuit journal, Studies in 1925: 'The Catholic Church has achieved an internationality beyond the wildest dreams of socialists or cosmopolitan theorists. Rome is the seat of the mightiest Internationale the world has ever seen. ${ }^{68}$

This aspiration to shape a Catholic alternative to socialist collectivism and unfettered capitalism matured most fully in the Anglophone world in the distributist thought of G. K. Chesterton and Hilaire Belloc. Drawing on the Catholic principle of subsidiarity, as expounded by Pope Leo XIII in Rerum Novarum (1891) and restated by Pope Pius XI forty years later in Quadragesimo Anno (1931), distributism advocated the redistribution of the means of production to as many people as possible. This was intended to redress the bifurcation of the labouring process that was perceived as an inevitable outcome of the capitalist wage system and to create 'a society in which the determinant mass of families are owners of capital and of land' and are, therefore, capable of living independent of any centralised state apparatus. ${ }^{69}$ Part of the corporatist movement that received Papal sanction in the 189os, distributism perceived competition for material wealth as spiritually demeaning and held

65 Henry Somerville, 'An Alternative to Capitalism [with Comments],' Studies 14 (1925): 529, https://www.jstor.org/stable/30093221.

66 James Chappel, Catholic Modern: The Challenge of Totalitarianism and the Remaking of the Church (Cambridge, MA: Harvard University Press, 2018), 4.

67 Giuliana Chamedes, A Twentieth-Century Crusade: The Vatican's Battle to Remake Christian Europe (Cambridge, MA: Harvard University Press, 2019), 15.

68 Stephen J. Brown, 'Catholic Internationalism,' Studies 14 (1925): 477, https://www.jstor.org/ stable/30094263.

$69 \quad$ Hilaire Belloc, The Servile State (London: T.N. Foulis, 1912), 52. 
that business, labour, and the state should cooperate to set quotas, prices, and wages throughout designated, vertically connected sectors of the economy, to be called Associations or Corporations. Rooted in a biologised conception of society as a corporate organism akin to the human body (or corpus), with individuals, families, vocational groups and trade unions functioning in the manner of cells, organs and tissues, corporatism was premised on a fundamental conviction that most human flourishing can be obtained when society is organised in a legitimate hierarchy guided by the Church. In this regard Jay P. Corrin notes that 'Distributism was not an oddity, out of step with modern culture ... it represented the single most important synthesis of Catholic social and political thinking to emerge in the English-speaking community in the early twentieth century. ${ }^{\prime}$

Distributism exerted an important, yet conspicuously undertheorised, influence over the political thought of Ireland's revolutionary generation. ${ }^{71}$ Chesterton and Belloc were preoccupied with Ireland in their imagining of an alternative Catholic future for Europe and contributed actively to the Irish debate over modernity in the pages of Studies. ${ }^{72}$ Both scholars regarded Ireland as a 'paradox . . . in the modern world, ${ }^{73}$ a predominantly rural, agricultural society that had resisted 'the revolt against Catholic morals which became definite in the sixteenth century', ${ }^{74}$ and which, despite enduring 'prolonged and insanely violent persecution, ${ }^{75}$ 'heroically preserved' that which Britain, 'utterly cut off from the unity of Christendom', had forfeited: a 'perfect integrity with the soul of Europe which is the Catholic Church. ${ }^{76}$ Irish Catholic intellectuals, such as Tierney, Collins, Blythe and FitzGerald, ${ }^{77}$ were engaged deeply with these debates and their imaginings of an alternative political future for

Jay P. Corrin, Catholic Intellectuals and the Challenge of Democracy (Notre Dame, IN: Notre Dame University Press, 2002), 15.

For instance, no reference is made to Belloc or Chesterton in R.F. Foster, Vivid Faces: The Revolutionary Generation in Ireland, 1890-1923 (New York: W.W. Norton, 2014).

See, for example, Hilaire Belloc, 'On Progress,' Studies 9 (1920): 497-511; G.K. Chesterton, 'The Mission of Ireland,' Studies 21 (1932): 374-384.

G.K. Chesterton, Irish Impressions (London: W. Collins, 1919), 28; see also Christendom in Dublin: Personal Impressions of the 31st Eucharistic Congress in Dublin 1932 (London: Sheed \& Ward, 1933). See Belloc's contribution to Somerville, 'An Alternative to Capitalism [with Comments],' 532. Hilaire Belloc, First and Last (London: Methuen \& Co., 1911), 94.

Hilaire Belloc, Europe and the Faith (London: Constable, 1920), 286, 311, 313.

For Collins, see the IHS Press Directors' preface to G.K. Chesterton, Irish Impressions (Norfolk, VA: I Hs Press, 2002), 9-11. For Blythe, see Tom Garvin, Nationalist Revolutionaries in Ireland 1858-1928: Patriots, Priests and the Roots of the Irish Revolution (Oxford: Oxford University Press, 1987), 165. For FitzGerald, see Regan, Counter-Revolution, 280-281. 
an independent Irish state can only be understood properly in the context of a broader, Europe-wide effort to shape a distinctly Catholic form of modernity. This project did not need to culminate inevitably in a repudiation of democracy. The relation of Catholic corporatist thought to fascism is complex and contested; ${ }^{78}$ indeed, organicist, corporatist influences are observable in the rhetoric of several Treatyite politicians whose commitment to parliamentary democracy never wavered. Addressing the Catholic Truth Society of Ireland in 1923, for instance, the notoriously hard-line Minister for Home Affairs, Kevin O'Higgins advocated 'an organic conception of society in which we are inseparable members, as truly as branches of a tree', stressing that 'When the tree withers' through bursts of 'individualism in excelsis', such as that which he perceived manifest in anti-Treaty insurrection, 'the branches also die. ${ }^{.79}$ President of the Executive Council, W.T. Cosgrave reflected similarly that: 'The body is composed of many members, each having his own distinct and definite duties to perform. You cannot neglect or injure any one of them without hurting the human constitution as a whole.' 80

Such rhetoric makes clear that it is possible to endorse an organic vision of society, one emphasising the primacy of citizens' obligations to the collectivity over individual liberties, without necessarily repudiating democracy. Indeed, Samuel Moyn has argued forcefully that in recognising the dignity and freedom of the individual' as the foundation of 'true social order', Éamon de Valera's 1937 constitution, Bunreacht na hÉireann deviated from the corporatist dignity claims that dominated interwar Catholic social theory and anticipated the reconciliation of Catholic personalism with democracy and human rights after World War II ${ }^{81}$ However, the potential for Catholic thinkers espousing corporatist conceptions of society to be drawn to authoritarian policies is obvious, particularly in a circumstance when illiberal structures of governance were in receipt of Papal sanction. ${ }^{82}$ Thus, just as the Catholic modernism of thinkers

78 See, for example, Philip Morgan, 'Corporatism and the Economic Order,' in The Oxford Handbook of Fascism, ed. R. J. B. Bosworth (Oxford: Oxford University Press, 2009), 150-165; António Costa Pinto, 'Fascism, Corporatism and the Crafting of Authoritarian Institutions in Inter-War European Dictatorships,' in Rethinking Fascism and Dictatorship in Europe, ed. António Costa Pinto and Artistotle Kallis, 87-120.

Kevin O'Higgins, The Catholic Layman in Public Life: An Address to the Catholic Truth Society (Dublin: Catholic Truth Society, 1923), 13.

8o Speech on Arthur Griffith and Michael Collins, 1923, University College, Dublin Archive (UCDA), W.T. Cosgrave Papers, P285/311.

81 Samuel Moyn, Christian Human Rights (Philadelphia: University of Pennsylvania Press, 2015), 25-64.

82 Martin Conway, Catholic Politics in Europe 1918-1945 (London: Routledge, 1997), 37-39. 
such as Belloc grew increasingly radicalised in response to shifting international political circumstances in the 1930s, so too did certain conceptions of Irish-Ireland nationalism. ${ }^{83}$ The development of Tierney's intellectual output in the decade following the publication of Education in a Free Ireland illustrates this dynamic vividly.

\section{Hybrid Solutions to a Growing Crisis}

As early as 1920 Tierney expressed significant misgivings regarding Ireland's relation to the modern world and attempted to chart-out a distinctive GaelicCatholic future, one influenced deeply by neo-medieval and Thomistic currents in contemporary Catholic social teaching. ${ }^{84}$ Writing in the aftermath of the of the Great War, an event that persuaded politicians, artists and intellectuals across Europe to reappraise the Enlightenment vision of modernity as a universal agent of human progress and emancipation based on reason, Tierney judged 'the survival of Christianity in Ireland', and the persistence of a medieval culture 'only on the fringe of the industrial vortex', to be 'the greatest of all our advantages', rendering the nation 'more readily susceptible to Christian ideals and influences than almost any other in Europe'. He argued that at a time when continental European nations, 'sickened and staggering after the mental lapse of the last four years...[are] struggling to adapt their most un-Christian environment to a somewhat more Christian idea of life', even 'the most cautious independent government' in Ireland would benefit for having 'only an insignificant legacy of [the] greedy folly' of liberal, industrial, capitalist modernity 'to sweep away'. ${ }^{55}$ Drawing on a combination of Catholic and republican sources, notably the educational writings John Henry Newman and Patrick Pearse, ${ }^{86}$ Tierney depicted the narrowly economistic, utilitarian educational philosophy of the Victorian English state as 'intrinsically abhorrent to the more spiritual Irish mind' and held that because 'We in Ireland have had so little part, as Irishmen, in shaping the structure of the time [in which] we live...we may lawfully deny responsibility for it. ${ }^{\prime 87}$ Seventeen-years

83 Jay P. Corrin, G.K. Chesterton \& Hilaire Belloc: The Battle Against Modernity (Athens, OH, 1981).

84 For more on the revival of Thomism, see Alasdair MacIntyre, God, Philosophy, Universities: A Selective History of the Catholic Philosophical Tradition (Lanham, MD: Rowman \& Littlefield, 2009), 151-164.

85 Tierney, Education in a Free Ireland, 20-21.

86 Ibid., $53-55$.

87 Ibid., 13 . 
later, Desmond FitzGerald reflected similarly that where 'Other countries grew into the modern world, we [in Ireland] were uprooted and plunged into it.'88 The foremost task of a native government, therefore, would be to fashion a specifically Irish variant of modernity, one that would avoid the pitfalls of mass, liberal, industrial societies and retain a connection to the ancient virtues and strong bonds of communal solidarity held to have animated Irish social life prior to the sixteenth-century. As Tierney put it, the first government of an independent Irish state must 're-establish an Irish civilisation, to bridge over the ragged breach which sunders our continuity with the old Gaelic Ireland . . - [and] to ensure that the development of the Gaelic nation will henceforth be continuous and uniform on its own lines.' 89

This sense that it was incumbent upon Irish nationalists to cast a critical eye on the 'contours' of the 'modern world', to recognise that it is not 'the only building' in which it is possible for the Irish race to dwell, and to 'and make up our minds what we are going to use it for if we do enter it' 90 was the animating insight of Tierney's political thought and is essential to understanding his growing interest in corporatist solutions to the crises of the interwar period. For from a very early stage in his political career, Tierney, like many fellow nationalists, was searching openly for a more Christian and, therefore, authentically Gaelic alternative to the system of economic, social and political liberalism which he perceived as having been inherited unthinkingly from the period of British rule. He was, furthermore, highly conscious of the openness of the future and the possibility that, under modern conditions, radically different models of social and economic organisation could be realised. ${ }^{91}$ This openness to bold new forms of social and political organisation intensified in the aftermath of the Wall Street Crash as increased social conflict placed unprecedented strain on democratic states across Europe.

In Tierney's analysis the onset of global economic depression set the inadequacy of 'Americanism', a phrase invoked as a synonym for unfettered capitalism, and 'Bolshevism' in sharp relief and underlined the imperative that Europe begin 'working out his own salvation' from the crisis of the interwar period 'in

88 Untitled speech or article dealing with Ireland's ability to resist communism, 1937, UCDA, FitzGerald Papers, P8o/1364.

89 Tierney, Education in a Free Ireland, 26.

$90 \quad$ Ibid., 12-13, 29-33.

91 Michael Tierney, 'Ancient Tyranny and Modern Dictatorship,' Studies 15 (1926): 195, 203, https://www.jstor.org/stable/30o93264. 
his own way. ${ }^{92}$ Drawing on the insights of contemporary critics of mass society such as Max Nordau and José Ortega y Gasset, Tierney perceived contemporary European civilisation as decadent and declining - an epoch 'marked by an unparalleled feeling of self-dissatisfaction' - and judged the 'world crisis' as 'not only economic and political', but as 'social, intellectual, and spiritual as well. ${ }^{93}$ 'All old values, of every kind, even the value of non-recognition of any value, are being called in question', Tierney observed; it was only by returning to 'Christendom', he concluded, that European civilisation could exert 'disciplinary force' over the destabilising influences of industrialisation and democracy and thereby ameliorate the 'appetitive, violent, intolerant, and above all indocile' tendencies of 'mass man', ${ }^{4}$ instincts that, left unregulated, lead inevitably to an atheistic worship of the state.

This growing 'consciousness of crisis', ${ }^{95}$ a sense that European civilisation, deprived of its traditional bonds of Christian unity, was sleep-walking towards another catastrophe on the scale of 1914, persuaded Tierney to adopt a more radical approach in his quest to ensure that the Free State might recover a more Christian ideal of life. Furthermore, in the context of the social unrest that followed Fianna Fáil's accession to executive power, Tierney, like many Treatyite intellectuals, feared the country to be succumbing irrevocably to the atomising sectionalism and class-conflict characteristic of what Pearse termed the 'great Christless cities' of 'England and America'. ${ }^{96}$ As early as 1927, Desmond FitzGerald contrasted the increased 'social atomisation' of Free State politics in the years following Fianna Fáil's entry into the Dáil with 'the spirit of Italy' under Mussolini, where 'even the humblest road worker felt that he was working for not merely so many pounds a week, but that he was working for the glory of Italy'. He concluded that Irish citizens needed to rediscover a consciousness 'of their community of interests' and renounce 'individual antagonisms' if a traditional sense of 'unity among the people' is to be restored. ${ }^{97}$ Italian, Portuguese and Austrian-style corporatism, with its emphasis on the interconnectedness of humanity and the need for a systematic and stable social order rather than opportunities for the competitive pursuit of individual material advancement, provided thinkers such as Tierney and FitzGerald

Michael Tierney, 'Review: The Re-Discovery of Europe,' Studies 21, no. 83 (1932): 426, 432, https://www.jstor.org/stable/30095249. Tierney also discusses Nordau's influential 1892 diagnosis of civilization decay, Degeneration in this review.

94 Ibid., 428-429.

95 Ibid., 424.

96 Pearse, 'From a Hermitage,' in Collected Works of Pádraic H. Pearse, 179.

$97 \quad$ Irish Times, 23 March 1927. 
with an attractive policy framework to realise the kind of neo-medieval society imagined in Education in a Free Ireland.

Responding to the nationalist politician and solicitor, John J. Horgan's call for the institution of a more autocratic system of government in 1933, for instance, Tierney dismissed as 'silly' the liberal 'notion' that 'every kind of cranky, or insignificant minority has a right to interfere with the work of government', and avowed 'that many of the legislative functions of Parliament might more usefully be assigned to vocational corporations under judicial guidance. ${ }^{\prime 98}$ The following year, he informed an audience in Drogheda that the corporate policies advocated by the new Fine Gael party 'would give a better semblance of the organised Christian society than the country has at present'. While Tierney tended to deny that Fine Gael's corporate scheme was 'anti-labour', 'anti-democracy' or 'Fascist', he avowed firmly that it would remedy the failings of an alien system of 'Parliamentary Democracy' introduced into Ireland by Oliver Cromwell and would move the Free State into line with 'great leaders' of Catholic countries 'all over the Continent'. This project by no means necessitated the establishment a dictatorship; for although Tierney professed public admiration for Mussolini and endorsed ideas developed by fascist intellectuals such as Fausto Pitigliani and Giuseppe de Michelis, ${ }^{99}$ his scepticism of democracy was always counterbalanced with a Belloc-like hostility to excessive state power. Tierney warned repeatedly that 'Bolshevism as well as Communism are only the logical conclusion of that Parliamentary system under which the State is everything and the individual is nothing except at election times', and while he drew attention to the achievements of other European 'Catholic leaders' in promoting corporatism, he principally emphasised 'the authority of the present Pope' as a justification for Fine Gael policy. ${ }^{100}$ In this regard, his engagement with Italian, Spanish and Austrian politics in the 193os can be seen as typical of the 'hybridisation' that scholars such as Roberts, Kallis and Costa Pinto emphasise as the defining characteristic of interwar fascist thought. For like conservative, Catholic intellectuals in contemporary Austria, Spain and Portugal, Tierney looked to Fascist Italy as a source of inspiration for the practical implementation of papal teachings, and borrowed from the

98 John J. Horgan, 'The Problem of Government [with Comments],' Studies 22 (1933): 558, https://www.jstor.org/stable/30095070.

For Tierney's reference to Fausto Pitigliani's The Italian Corporative State (New York: Macmillan, 1933), see UCDA, Tierney papers, LA30/349. For his reference to Giuseppe de Michelis' World Reorganisation on Corporative Lines (London: George Allen and Unwin, 1935), see Michael Tierney, 'Colonial Policy and European Peace,' Studies 24 (1935): 429-442. 
Italian example, and other hybrid forms of fascism, to formulate his own, specifically Gaelic-Catholic solution to 'the great social and economic crises of the post war world. ${ }^{\prime 101}$

Tierney's call for the corporatist renovation of Free State politics was expressed most fully in a 1934 article entitled 'Ireland and the Reform of Democracy'. Drawing on the corporatist thought of the Lille economist, Bernard Lavergne, ${ }^{102}$ as well as the Thomist proscriptions laid down by 'the present Pope in his great Encyclical of $1931,{ }^{1}{ }^{103}$ he poured scorn on 'the traditional belief that the wisdom of the community can be best found by counting heads' ${ }^{104}$ and encouraged readers to consider 'that in modern as in ancient times it may be necessary for democracy to die in order that civilisation may continue to live.'105 Emphasising that, historically, 'military dictatorship has been the most lasting of all methods of ruling civilised people', Tierney stressed that democracy has always been a 'flower of delicate nature and brief duration' and, like many Catholic conservatives in the 1930s, he perceived liberal parliamentarianism as fundamentally ill-equipped to deal with the challenges posed by mass, modern societies. ${ }^{106}$ Indeed, he was convinced that 'only in one country, Italy is there any sign of an attempt to create out of the wreckage both of Parliament and party, a really well-designed and complex machinery for dealing with a complex situation.' ${ }^{107}$ 'It is time that we should create a system of government capable of meeting the needs of modern civilisation', Tierney declared: 'In Ireland more than anywhere else we need a renovation both of the theory of democracy and its practice. Both must be finally and inexorably divorced from the superficial mysticism of the French Revolution, the visionary materialism of the English Liberal school, and the confused and inadequate mechanisms which revolutionaries and radicals have imposed upon older political theories and systems. ${ }^{108}$

In making this argument, Tierney was essentially recapitulating sentiments that he expressed first in Education in a Free Ireland fourteen years earlier. Indeed, the only significant difference between the two texts is that where

\footnotetext{
$101 \quad$ United Ireland, 16 December 1933.

102 Le Gouvernement Des Democraties Modernes (Paris: Félix Alcan, 1933) is the first text cited in the article.

103 Michael Tierney, 'Ireland and the Reform of Democracy,' Studies 23, no. 91 (1934): 374, https://www.jstor.org/stable/30079848.

104 Tierney, 'Ireland and the Reform of Democracy,' 380.

105 Ibid., 371.

$106 \quad$ Ibid., 369.

107 United Ireland, 16 December 1933.

108 Tierney, 'Ireland and the Reform of Democracy,' 372.
} 
Education in a Free Ireland avowed confidently that 'with right education' democracy can be 'inevitable and everlasting'; 109 by the 1930s, international circumstance had persuaded him to reappraise his perception of the Irish public's capacity to bear 'the awful responsibility that falls upon the shoulders of the individual citizen' under a liberal, democratic system of government. ${ }^{110}$ He consequently determined that democracy was incompatible with the preservation of Ireland's civilisational distinctiveness under the conditions of modernity and expressed regret that it should have been Austria, and not the Free State, that was 'first to undertake the establishment of a political system based rather on Catholic philosophical principles than on the relics of 19th century parliamentarian radicalism.'111 It should come as no surprise, therefore, that Tierney, like the rest of the Blueshirt leadership, never ceased to conceive of his politics in continuity with the revivalist nationalism that animated the revolution. In his analysis, the institutionalisation of a Catholic corporate state was the most effective means by which the customs, instincts and ideals of Gaelic Ireland could be transmitted into modern conditions, thus enabling an independent Irish state to stave-off the utilitarianism and decadence that nationalist intellectuals had long presented as anathema to Ireland's social and cultural traditions. As the organisation's charismatic leader, Eoin O'Duffy stated boldly at a mass rally in 1934: 'The spirit of Michael Collins is abroad today, the nation is once more upon the march, who dares cry "Halt" to us?'112

\section{Conclusion}

In an essential examination of Tierney's political career, Peter Martin observed that, after 1934, a 'combination of anti-fascist criticism and state repression of the Blueshirts' persuaded Tierney to 'move away from anti-democratic rhetoric' and to lay a greater emphasis on the 'positive arguments for his ideas'.113 However, he never ceased to argue that parliamentary democracy led inevitably to an excessive accumulation of power in the bureaucratic apparatus of the administrative state, and continued to advocate corporatist structures as a bulwark against what he, following Belloc, termed the 'servile State.114 Furthermore, he never repudiated the claim, first expounded in Education in

\footnotetext{
109 Tierney, Education in a Free Ireland, 23.

$110 \quad$ Ibid., 97.

111 Tierney, 'Ireland and the Reform of Democracy,' 382.

112 Cork Examiner, 3 September 1934.

113 Martin, 'The political career of Michael Tierney,' 422.

114 Seanad Éireann, 13 July 1938.
} 
a Free Ireland, that the Free State's political leadership needed to reconnect with Gaelic intellectual traditions if it was to succeed in its principal task of preserving the nation's ethnic distinctiveness under modern conditions. Responding to Seán Ó Faoláin's influential 1938 biography of Daniel O'Connell in Studies, for instance, Tierney argued that because 'nationalism ... [is] itself for the most part a thing of English origin', the Irish nationalist tradition had politically internalised much of that which it set out to oppose and had consequently rendered the Irish people vulnerable 'to that most dreadful of all fates, the awful emptiness of a nation without a history.'115 'Democracy', in Tierney's analysis, was 'no substitute for culture',116 and he remained convinced that only the institution of a truly Christian model of governance could enable the Irish nation to thrive in modernity without succumbing to 'the incongruous mixture' of 'etiolated Catholicism, puritanical individualism and commercial utility' that marked the English liberal tradition. ${ }^{117}$

From 1920 to 1938 , therefore, the fundamental political principles underlying Tierney's intellectual output exhibit a remarkable continuity. He, like many nationalists of his generation, aspired for an independent Irish state to eschew the commercialism of British liberal culture and institutionalise a state based on the philosophical principles of the Catholic Church. What changed in Tierney's political thought in the 1930s was not his fundamental ideological beliefs, but his perception of the political system best placed to realise them. This strategic reappraisal came about as a direct result of his engagement with political ideas, debates and institutional developments outside of Ireland. He was influenced, too, by the criticisms of mass, democratic society proffered by the Catholic Church and fascist intellectuals on the European continent. In this regard, the radicalisation of Tierney's political thought in the 1930s, and that of the Blueshirt movement more broadly, can be assessed productively through the lens of fascist hybridisation theory: he was one of many politically conservative, Catholic nationalists who was drawn into the political-gravitational field of fascism in seeking to develop institutional and policy responses to the unprecedented challenges of the interwar period. The Blueshirts, therefore, should assessed not as a break with the liberal, democratic essence of Treatyite politics, nor as an abortive manifestation of fascism "proper", but as a fascistised expression of long established and deeply embedded tendencies in the nationalist and

115 Michael Tierney, 'Politics and Culture: Daniel O'Connell and the Gaelic Past,' Studies 27, no. 107 (1938): 359, 367, https://www.jstor.org/stable/30097570.

116 Tierney, 'Politics and Culture,' 368.

117 Ibid., 367 . 
republican traditions that animated the revolution. Indeed, it is only by tracing the intellectual trajectory of figures such as Tierney that we can hope to come to a fuller comprehension both of the Blueshirts' self-understanding and the movement's relation to continental fascism. For more important than whether the Blueshirts met the taxonomic specificae of models of generic fascism theorised retrospectively in contemporary scholarship, is the question of how the movement conceived of its relation to, and interacted with, other conservative nationalist movements as fascism developed gradually and unpredictably in the 1920 and 3 os. 